\title{
Power requirements of an imprinter and rangeland drill
}

\author{
DALE E. WILKINS, MARSHALL R. HAFERKAMP, AND DAVID C. GANSKOPP
}

\begin{abstract}
Energy requirements for a land imprinter and rangeland drill,

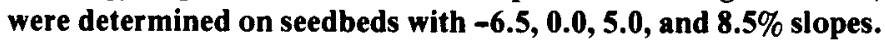
The imprinter was tested empty $(1.3 \mathrm{Mg} / \mathrm{m})$, full $(1.9 \mathrm{Mg} / \mathrm{m})$, and half-full $(1.67 \mathrm{Mg} / \mathrm{m})$ of water. The rangeland drill was half width (1.5 $\mathrm{m}$ wide). Each implement was pulled over 4 replicated 23-m runs per slope. During each test run we recorded speed of travel and $\mathbf{1 0}$ drawbar force measurements, sensed with a load cell and integrated over 100 milliseconds. A procedure outlined by the American Society of Agricultural Engineers was used to estimate cost of use for a $3-\mathrm{m}$ wide rangeland drill and imprinter $3 / 4$ full of water. A 5-year implement age and 100 hours use per year were assumed. Operating costs for the land imprinter and rangeland drill were $\$ 56.92 /$ ha and $\$ 40.27 /$ ha, respectively, excluding grass seed.
\end{abstract}

Key Words: range seeding, imprinter, drill, economics, power

The land imprinter and the imprinting revegetation system appear to be effective for covering broadcast seed and for creating micro-depressions to reduce runoff on rangelands (Dixon and Simanton 1980, Anderson 1981). Results from seeding by imprinting have been variable in the southwestern United States, where much of the precipitation occurs as intense summer rains (Dixon 1983, Cox et al. 1986). Seedling emergence was improved by imprinting compared to drilling on burned seedbeds in Utah (Clary and Johnson 1983), and on mowed-disced seedbeds in southeast-

\footnotetext{
Authors are agricultural engineer, USDA-ARS, Columbia Plateau Conservation Research Center, Pendleton, Oregon 97801; plant physiologist, USUA-AKS, Ft. Keogh Livestock and Range Research Laboratory, Miles City, Montana 59301; and range scientist, USDA-ARS, Squaw Butte Station, Eastern Oregon Agricultural Research Center, Burns, Oregon 97720, respectively. Joint contribution of the USDAARS and Oregon State University Agricultural Experiment Station Technical Paper 8782 .

The authors greatly acknowledge the cooperation of Mac Levy of the Cunningham Sheep Company for providing land for this study and the technical assistance of Larry Baarstad, agricultural research technician, USDA-ARS, Columbia Plateau Conservation Research Center, Pendleton, Oregon 97801.

Manuscript accepted 27 July 1989.
}

ern Oregon (Haferkamp et al. 1987b), and by imprinting compared to chaining after aerially broadcasting seed on burned seedbeds in southern Oregon (Ganskopp 1985, Haferkamp et al. 1987a). Successful stands of seedlings have been established by broadcasting seed in front of the imprinter at rates as low as 170 pure live seeds (PLS) $/ \mathrm{m}^{2}$ (Haferkamp et al. 1987a, 1987b).

Satisfactory stands of seedlings obtained by broadcasting seed before imprinting in Oregon suggest the technique is a viable alternative to drilling on loose seedbeds in the sagebrush-bunchgrass steppe. Adoption of this practice may, however, depend on cost differences between the 2 methods. Clary and Wagstaff (1987) reported the typical cost of imprinting in the intermountain region was $\$ 67 /$ ha compared to $\$ 42 /$ ha for drilling, but pulling and cost requirements for the rangeland drill and the land imprinter have not been presented in the literature. Our objective was to determine the energy requirement of the land imprinter and the half-width rangeland drill for seeding on different slopes.

\section{Materials and Methods}

Drawbar pull forces of a 2-m wide imprinter (Haferkamp et al. $1987 \mathrm{~b}$ ) and a 1.5-m wide rangeland drill were measured on a Ritzville silt loam (coarse-silty, mixed, calciorthidic, Haploxeroll) near Pendleton, Oregon. The soil contained 3.4 to $5.4 \%$ water on an oven-dry basis. The imprinter was tested empty $(1.30 \mathrm{Mg} / \mathrm{m})$, full $(1.90 \mathrm{Mg} / \mathrm{m})$ of water and one-half full $(1.67 \mathrm{Mg} / \mathrm{m})$ on plots $2.5 \mathrm{~m}$ wide by $23 \mathrm{~m}$ long with slopes of $-6.5,0.0,5.0$, and $8.5 \%$. The rangeland drill had new, regular, unweighted opener arms, $2.5-\mathrm{cm}$ depth bands and single disced openers (Young and McKenzie 1982). Both implements penetrated the soil adequately because the field had been tilled prior to tests. The 4 treatments (imprinter full, half-full, and empty and rangeland drill) were replicated 4 times on each slope. The implements were pulled with a crawler tractor that had a standard transmission and $23.3 \mathrm{~kW}$ of power. An Omni Data 
model 516 Polycorder $^{1}$ recorded travel speed and drawbar pull force from a load cell. Ten force measurements, each integrated over 100 milliseconds, were averaged for each 23-m run. Power was determined from the drawbar pull and travel speed. The data from each of the treatments were summarized by linear least squares regression of drawbar power on field slope.

The procedure outlined by ASAE (1987a) and ASAE data (1987b) were used to make an economic comparison of the imprinter and rangeland drill seeding methods. This analysis includes depreciation, taxes, housing, interest, insurance, repairs, labor, and assumes the implements are 5 years old and are used 100 hours per year for determining the operating costs of the seeders. The purchase prices of a 3-m rangeland drill and imprinter (including broadcast seeder) are $\$ 11,500$ and $\$ 9,625$, respectively.

\section{Results and Discussion}

Figure 1 shows the power required per meter of implement width on various slopes with travel speed of $1.78 \mathrm{~m} / \mathrm{s}$ for the 3 imprinter masses and the rangeland drill. The relationships between slope

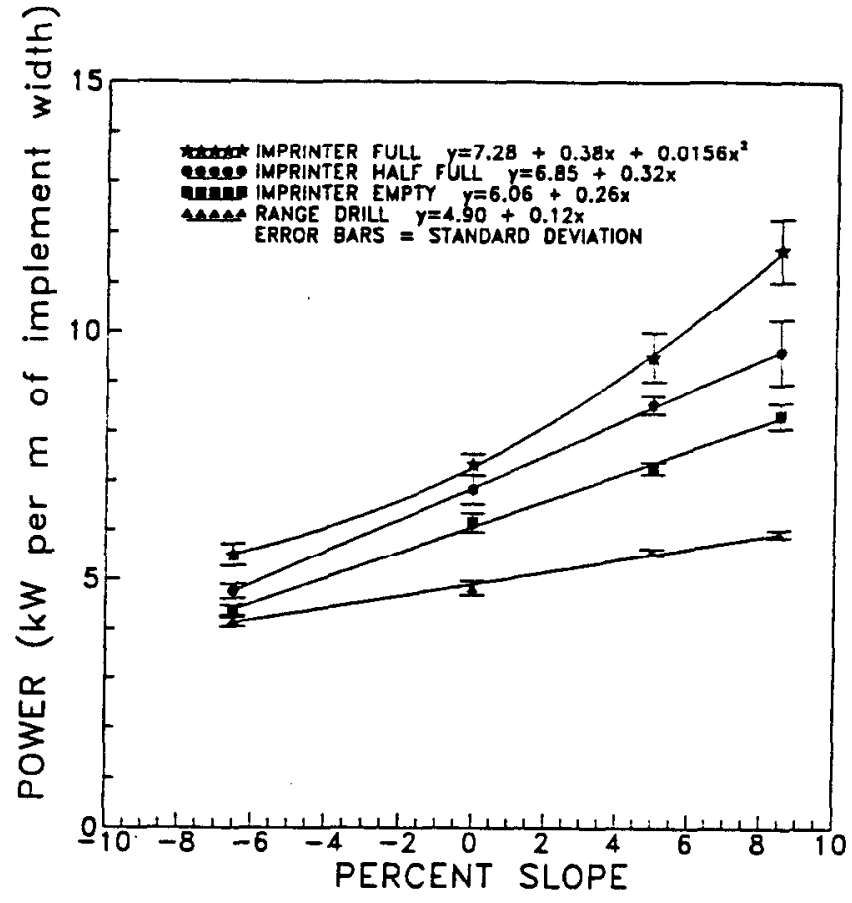

Fig. 1. Drawbar power requirements per meter of implement width as infuenced by percent slope.

and drawbar power for the imprinter half full, empty, and the rangeland drill were linear and therefore first degree polynomials were fit to these data. A second degree polynomial was fit to the curviliner data for the imprinter full. The polynomial equations and plots of these equations are shown in Figure 1. Imprinter and rangeland drill power requirements increased as slope increased, but rate of increase was greater for the imprinter. The rangeland drill required 35 and $50 \%$ less power per meter of implement width when compared to the imprinter full of water for 0 and $8 \%$ slopes, respectively.

At $1.78 \mathrm{~m} / \mathrm{s}$ and zero slope the rangeland drill draft requirements were 900 newtons $(\mathrm{N})$ per opener. This compares favorably with ASAE data of 450 to $800 \mathrm{~N} /$ opener for row crop planters (1987b).

Mention to a trademark or proprietary product does not constitute a guarantee or warranty of the product by U.S. Department of Agriculture and does not imply approval to the exclusion of other products that may also be suitable.
For level conditions our data indicate a full-sized 3-m rangeland drill would require the same power $(14.7 \mathrm{~kW})$ as a $2-\mathrm{m}$ imprinter 3/4-full of water. A 55 to $75 \mathrm{~kW}$ track-laying type tractor would be sufficient to pull either implement at the recommended speed of $1.78 \mathrm{~m} / \mathrm{s}$. Using an $80 \%$ field operating efficiency, tractor cost of $\$ 30 / \mathrm{hr}$, and labor cost of $\$ 10 / \mathrm{hr}$, (Bauscher and Willett 1984), the cost for labor and power to seed with a full size rangeland drill is $\$ 26.67 /$ ha and $\$ 40 /$ ha for the imprinter $3 / 4$-full of water. Increasing the weight of the imprinter increased the drawbar power required and subsequently the operating cost of the imprinter.

The operating cost of the rangeland drill is $\$ 13.60 /$ ha and the imprinter $\$ 16.92 /$ ha. Therefore, the cost of seeding, excluding seed, with the rangeland drill is $\$ 13.60 /$ ha for the drill plus $\$ 26.67 /$ ha for the tractor and labor or a total of $\$ 40.27 /$ ha. The seeding costs using the imprinter are $\$ 16.92 /$ ha for the implement and $\$ 40 /$ ha for the tractor and labor for a total of $\$ 56.92 /$ ha. Although the cost of imprinting is higher, this method may be necessary if satisfactory grass stands are not obtained from drilling on loose soils.

\section{Literature Cited}

Amer. Soc. Agr. Engr. ASAE Engineering Practice: ASAE EP391.1. 1987a. Agricultural machinery management. p. 212-215. In: R.H. Hahn and E.E. Rosentreter (eds.) ASAE Standards 1987: ASAE, St. Joseph, Mo.

Amer. Soc. Agr. Engr. Data: ASAE D230.4. 1987b. Agricultural machinery management data. p. 89-95. In: R.H. Hahn and E.E. Rosentreter (eds.) ASAE Standards 1987: ASAE, St. Joseph, Mo.

Anderson, R. 1981. A story in two parts, advance of the barren earth technology for reversing desertification. Rangelands 3:47-50.

Bauscher, L.D., and G.S. Willett. 1984. The cost of owning and operating farm machinery in Washington. Washington Agr. Exp. Sta. Bull. 1055.

Clary, W.C., and T.J. Johnson. 1983. Land imprinter results in Utah. p. 23-24. In: 37th Annu. Rep., Vegetative Rehabilitation \& Equipment Workshop. 13-14 February 1983. Albuquerque, N. Mex., USDA Forest Service, Equipment Development Center, Missoula Mont.

Clary, W.C., and F.J. Wagstaff. 1987. Biological and economic effectiveness of several revegetation techniques in the pinyon-juniper-sagebrush zone. p. 305-312. In: Everett, R.L. (compiler) Proc.-Pinyon-JuniperConf. 13-16 January 1986, Reno, Nev. USDA Forest Serv., Equipment Develop. Center, Missoula, Mont.

Cox, J.R., M.H. Martin-R., F.A. Ibarra-F, and H.L. Morton. 1986. Establishment of range grasses on various seedbeds at creosotebush (Larrea tridentata) sites in Arizona, U.S.A., an Chihuahua, Mexico. J. Range Manage. 39:540-546.

Dixon, R.M. 1983. Land imprinting activities. p. 13. In: 37th Annu. Rep., Vegetative Rehabilitation \& Equipment Workshop. 13-14 February 1983, Albuquerque, N. Mex. USDA, Forest Serv., Equipment Develop. Center, Missoula, Mont.

Dixon, R.M., and J.R. Simanton. 1980. Land imprinting for better watershed management. p. 809-826. In: Symp. on Watershed Management. Vol. II. 21-23 July 1980, Boise, Idaho. Amer. Soc. Civil Eng.

Ganskopp, D.C. 1985. Success of broadcast seeding on untreated, imprinted and chained rangelands. p. 4-6. In: 1985 Progress Report. Res. in Range Manage. Oregon Agr. Exp. Sta. Spec. Rep. 743.

Haferkamp, M.R., D.C. Ganskopp, R.F. Miller, F.A. Sneva, K.L. Marietta, and D. Couche. 1987a. Establishing grass by imprinting in the Northwestern United States. p. 299-308. In: G.W. Frasier, and R.A. Evans (eds.). Proc. Seed and Seedbed Ecology of Rangeland Plants. 12-13 April 1987, Tucson, Ariz.

Haferkamp, M.R., D.C. Ganskopp, R.F. Miller, and F.A. Sneva. 1987b. Drilling versus imprinting for establishing crested wheatgrass in the sagebrush-bunchgrass steppe. J. Range Manage. 40:524-530.

Young, J.A., and D. McKenzie. 1982. Rangeland drill. Rangelands. 4:108-113. 